\title{
In -Vitro Antioxidant Activity of Methanolic Extract of the Roots of Bergenia ciliate
}

\author{
Suman Lal Shrestha ${ }^{1}$, Suresh Awale ${ }^{2}$, Surya Kant Kalauni ${ }^{* *}$ \\ ${ }^{l}$ Department of Chemistry Patan Multiple Campus, Patan, Lalitpur, Nepal \\ ${ }^{2}$ Division of Natural Drug Discovery, Institute of Natural Medicine, University of Toyama, Japan \\ ${ }^{3}$ Central Department of Chemistry, Tribhuvan University, Kirtipur, Kathmandu, Nepal
}

*Corresponding Author: Surya Kant Kalauni, Central Department of Chemistry, Tribhuvan University, Kirtipur, Kathmandu, Nepal

\begin{abstract}
Bergenia ciliata is an important medicinal plant used in regions where western medicines are inaccessible due to their unavailability and high cost. The methanolic extract of Bergenia ciliataroots was screened for phytochemical constituents and in-vitro antioxidant activity. The plant extract showed the rich source of secondary metabolites that play the role for biological activities.The higher antioxidant activity of the plant is due to the presence of reactive constituents like phenols and flavonoids. The antioxidant activity of the plant extract was measured by DPPH free radical scavenging assay. In DPPH free radical scavenging assay the $I C_{50}$ value of Bergenia ciliata was found to be $11.21 \mu \mathrm{g} / \mathrm{mL}$, while the $I C_{50}$ value of standard ascorbic acid was found to be $45.93 \mu \mathrm{g} / \mathrm{mL}$
\end{abstract}

Keywords: antioxidant, DPPH, free radical scavenging, medicinal plants, methanolic extract.

\section{INTRODUCTION}

Bergenia ciliata is a well- known medicinal herb with thick rootstocks, 3.5 to $16.5 \mathrm{~cm}$ long. The plant is distributed throughout Nepal at 1300-3000 m in moist, rocky places (Manandhar, 2002). Medicinal and aromatic plants play vital role in for livelihood health and socio-economic prospects of the country.The majority of Nepal's population, especially tribal, ethnic groups and mountain people relies on traditional medical practices (Ajayi et al. 2011). In many cases this practice is transmitted orally from generation to generation and confined to certain people (Edeogn et al. 2005). In present study plant sample was collected from Manang district of Nepal to analize its antioxidant activity and total phenol and flavonoid content. Antioxidant research is an important topic in the medical field as well as in the food industry. Antioxidants are compounds that protect cells against the damaging effects of reactive oxygen species, such as singlet oxygen, superoxide, peroxyl radicals, hydroxyl radicals and peroxynitrite (Hafiza et al. 2002). An imbalance between antioxidants and reactive oxygen species results in oxidative stress, leading to cellular damage. Oxidative stress has been linked to cancer, aging, atherosclerosis, ischemic injury, inflammation and neurodegenerative diseases (Arutselvi et al. 2012 \& Igbinosa et al. 2009). Oxidants are capable of stimulating cell division, which is a critical factor in mutagenesis when a cell with a damaged DNA stand divides. Thus, mutation can arise which in turn is an important factor in carcinogenesis. Both cigarette smoking and chronic inflammation are of the major causes of cancer have strong free radical components in their mechanism of action.Flavonoids may help provide protection against these diseases by contributing, along with antioxidant vitamins and enzymes, to the total antioxidant defense system of the human body. Epidemiological studies have shown that flavonoid intake is inversely related to mortality from coronary heart disease and to the incidence of heart attacks (Tamilarasi et al. 2012). Flavonoids are most commonly known for their antioxidant activity and the capacity of flavonoids to act as antioxidants depends upon their molecular structure. The position of hydroxyl groups and other features in the chemical structure of flavonoids are important for their antioxidant and free radical scavenging activities (Fernandez et al. 2004). Quercetin, the most common dietary flavonol, is a potent antioxidant, because it has all the right structural features for free radical scavenging activity. It is generally assumed that frequent consumption of plant derived phytochemicals from vegetables, 
fruits, tea and herbs may contribute to shift the balance toward an adequate antioxidant status (Dehshahri et al. 2012). In the present study, antioxidant activity of the methanolic bark extract of Bergenia ciliata was evaluated by using 1,1-diphenyl-2-picrylhydrazyl (DPPH) scavenging assay.

\section{MATERIALS AND MeTHOD}

\subsection{Plant Materials}

The plant sample was collected in month of June from the Manang district of Nepal based on the ethnobotanical uses. The plant sample was identified at the National Herbarium and Plant Laboratories Government of Nepal, Godawari, Lalitpur.

\subsection{Extraction}

The plant sample was shade dried at room temperature and powderedmaterial was then weighed (50 g), soaked in methanolfor $72 \mathrm{~h}$ and filtered using Whatman No 1 filter paper. The filtrate obtained was concentrated under reduced pressure in a rotatory evaporator to obtain the crude extract. The crude extract was used for further investigation of phytochemical constituents, total polyphenol content, flavonoid content and antioxidant properties.

\subsection{Phytochemical Screening}

Phytochemical analysis of crude methanolic extracts of these medicinal plants was carried out based on the procedure described on the standard protocol (Sucheta et al. 2011 \& Saha et al. 2008).

\subsection{Antioxidant Activity Test}

\section{DPPH Radical Scavenging Activity}

The free radical scavenging activity was measured by using DPPH assay. Different concentration of test samples $(5,10,20,30,40,50,60,70,80,90,100 \mu \mathrm{g} / \mathrm{ml})$ were prepared while the concentration of DPPH was $0.2 \mathrm{mM}$ in the reaction mixture. These reaction mixtures were taken in Eppendorf tubes and incubation at $37{ }^{\circ} \mathrm{C}$ for $30 \mathrm{~min}$. Discolorations were measured at $517 \mathrm{~nm}$ using a UV-Visible Spectrophotometer. Percent radical scavenging activity by sample treatment was determined by comparison with methanol treated control group; ascorbic acid was used as positive control. Measurement was performed at least in triplicate. The percentage scavenging of the DPPH free radical was calculated using the following equation:

$\%$ Scavenging Activity $=$ Absorbance of the control - Absorbance of the test sample $\quad$ X 100

\section{Absorbance of the control}

The inhibition curve was plotted for the triplicate experiments and represented as percentage of mean inhibition \pm standard deviation and the $\mathrm{IC}_{50}$ values were obtained.

\section{RESULT AND DISCUSSION}

Phytochemical screening result showed that, plant extract was the potent source of phytochemical constituents like polyphenols, alkaloids, flavonoids, steroids, and tannin except steroids and carotenoids.

Table1. Phytochemical analysis of plant extracts

\begin{tabular}{|l|c|l|c|}
\hline Polyphenols & + & Reducing sugar & + \\
\hline Steroids & - & Tannin & + \\
\hline Alkaloids & + & Cardiac glycoside & + \\
\hline Flavonoids & + & Anthraquinone & + \\
\hline Terpenoids & + & Carotenoids & + \\
\hline Glycosides & + & Saponin & + \\
\hline
\end{tabular}

Key: $+=$ Present $\quad-=$ Absent

Free radicals are chemical entities that can exist separately with one or more unpaired electrons. The propagation of free radicals can bring about thousands of reactions and thus may cause extensive tissue damage. Antioxidants can act by converting the unpaired electrons to paired ones. The dose dependent inhibition of DPPH radical indicates that plant extract causes reduction of DPPH radical in a stoichiometric manner. The present study was carried out to analyze the antioxidant activity of the 
methanolic plant extract of Bergenia ciliata barks. The DPPH radical scavenging activity $\left(\mathrm{IC}_{50}\right)$ of the plant extract was found to be $11.21 \pm 1.8 \mu \mathrm{g} / \mathrm{mL}$.

Khalaf et al. (2008), has reported the antioxidant activity $\left(\mathrm{IC}_{50}\right)$ of some medicinal plants such as Camellia sinensis Linn. $6.7 \pm 0.1 \mu \mathrm{g} / \mathrm{ml}$, Eugenia caryophyllus (spreng) $9.9 \pm 0.2 \mu \mathrm{g} / \mathrm{ml}$, Zingiber officianale $65.1 \pm 1.7 \mu \mathrm{g} / \mathrm{ml}$, piper nigrium Linn. $144.1 \pm 2.2 \mu \mathrm{g} / \mathrm{ml}$ and Piper cubeba Linn. $11.3 \pm 0.3$ $\mu \mathrm{g} / \mathrm{ml}$ which are found similar to the present study. Regarding the antioxidant activity of some medicinal plants. Nikolova et al. 2011 reported that antioxidant values $\left(\mathrm{IC}_{50}\right)$ of some plant extracts such as Cardus nutans L, Leucojum aestivum L., Crithmumm aritimum L., Hedera helix L., Asparagus officinalis L., Fumaria officinalis L. and Daucus carota L. has $\mathrm{IC}_{50}$ greater than 200 $\mu \mathrm{g} / \mathrm{ml}$ which indicates the less potent antioxidant than that of present results. Sharma et al. (2015), has reported antioxidant activities of some selected medicinal plants of Nepal and it is found that plants are the rich sources of antioxidant compounds.

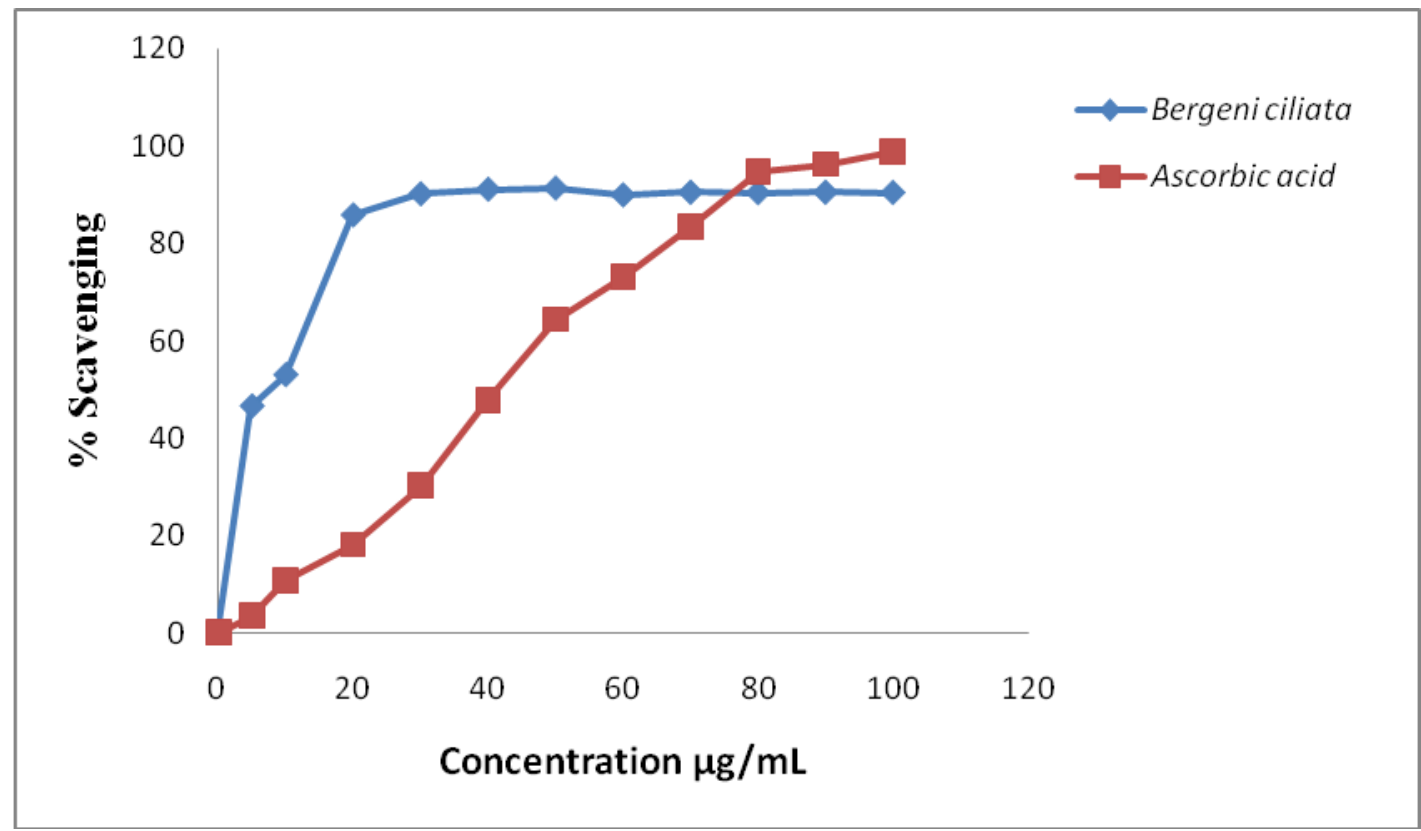

Fig1. Percentage scavenging of DPPH free radical with plant extract and ascorbic acid

\section{CONClusions}

Phytochemical analysis showed that the root extract of Berginia ciliata was rich source of secondary metabolites. Free radical scavenging activity showed that plant extract was the potent antioxidant with $\mathrm{IC}_{50}$ of $11.21 \pm 1.8 \mu \mathrm{g} / \mathrm{mL}$. But, the $\mathrm{IC}_{50}$ value of standard ascorbic acid was $45.93 \mu \mathrm{g} / \mathrm{mL}$. It showed the sample is the potent antioxidant than the standard ascorbic acid.

\section{ACKNOWLEDGEMENT}

The author is thankful to the Central Department of Chemistry, Central Department of Biotechnology and Central Department of Microbiology, Tribhuvan University, for providing some chemicals and laboratory facilities. The authors are also grateful to the National Herbarium and Plant Laboratories Godawari, Lalitpur for identification of the plant species.

\section{REFERENCES}

Ajayi, A., Ajibade, O. \& Oderinde, R. A. (2011). Preliminary Phytochemical Analysis of some Plant Seeds. Research Journal of Chemical Sciences, 1(3), 58-62.

Arutselvi, R., Balasaravanam, T., Ponmurugan, P., Muthu, N., Saranji, N. \& Suresh, P. (2012). Phytochemical screening and comparative study of anti microbial activity of leaves and rhizomes of turmeric varieties. Asian Journal of Plant Science and Research, 2(2), 212-219.

Dehshahri, S., Wink, M., Afsharypuor, S., Asghari, G. \& Mohagheghzadeh, A. (2012). Antioxidant activity of methanolic leaf extract of Moringa peregrina (Forssk.) Fiori, Research in Pharmaceutical Sciences.7(2), $111-118$.

Edeogn, H. O., Okwu, D. E. \& Mbaebie, B. O. (2005). Phytochemical constituents of some Nigerian medicinal plants, African Journal of Biotechnology.4, 685-688. 
Fernandez, S., Wasowski, C., Paladini, A. C. \& Marder, M. (2004). Sedative and sleep-enhancing properties of linarin, a flavonoid-isolated from Valeriana officinalis, Pharmcology Biochemistry Behavior, 77, 399-404.

Hafiza, M. A., Parveen, B., Ahmad, R. \& Hamid, K. (2002). Phytochemical and antifungal screening of Medicago sativa and Zinnia elegans, Online Journal of Biotechnology Sciences, 2 130-132.

Igbinosa, O. O., Igbinosa, E. O. \& Aiyegoro, O. A. (2009). Antimicrobial activity and phytochemical screening of stem bark extracts from Jatropha curcas, African Journal of Pharmaceutical and Pharmacology, 3 (2), 58-62.

Khalaf, A., Shakya, K., Al-othman,A., El-Agbar, Z. \& Farah, H. (2008). Antioxidant Activity of Some Common Plants, Turk Journal of Biology, 32, 51-55.

Manandhar, N. P. (2002). Plants and People of Nepal, Portland, Oregon.

Procestos, C., Lytoudi, K., Mavromelanidou, O., Zoumpouslakis, P. \& Sinanoglou, V. (2013). Antioxidant Capacity of Selected Plant Extracts and Their Essential Oils, Antioxidants, 2(1).11-22.

Saha, M. R., Hassan, S. M., Akter, R .\& Hossain, M. M. (2008). In vitro free radical scavenging activity of methanol extract of the leaves of Mimusops elengi Linn, Journal of Vetenerary Medicine, 6,197-202.

Sharma, K. R., Kalauni, S. K., Awale, S. \& Pokharel, Y. R. (2015). In-vitro free radical scavenging activity of methanol extracts of some selected medicinal plants of Nepal. Austin Journal of Biotechnology and Bioengineering, 2(1),1035.

Sucheta, A., Gayatri, S., Nirmala, R., Swati, D. \& Jyoti, P. (2011). In vitro evaluation of free radical scavenging potential of Cassia auriculata L, Journal of Chemical and Pharmaceutical Research. 3(4):766- 772.

Tamilarasi, T. \& Ananthi, T. (2012). Phytochemical Analysis and Anti Microbial Activity of Mimosa pudica Linn. Research Journal of Chemical Science, 2 (2) 72-74.

Citation: S. Shrestha et al., "In -Vitro Antioxidant Activity of Methanolic Extract of the Roots of Bergenia ciliate", International Journal of Advanced Research in Chemical Science (IJARCS), vol. 5, no. 8, pp. 1-4, 2018. http://dx.doi.org/10.20431/2349-0403.0508001

Copyright: (C) 2018 Authors. This is an open-access article distributed under the terms of the Creative Commons Attribution License, which permits unrestricted use, distribution, and reproduction in any medium, provided the original author and source are credited. 